\title{
THE REFERENDUM ON ARTIFICIAL INSEMINATION
}

\author{
Chiara Martini
}

On 12 and 13 June 2005, the citizens of Italy were called to the polls to vote on law no. 40 of 19 February 2004, which for the first time in Italy established regulations on medically assisted reproduction (MAR). This law, even if it arrived later in Italy than in other European countries, was not suddenly "born." Its adoption came about after a long and tormented debate that concluded with the approval of a text supported by a majority that crossed the boundary between the two political coalitions, which included almost the whole of the center-right and the majority of the Margherita. The four referendum questions, proposed by representatives of the left and supported by the Radical movement, aimed to introduce modifications to the law, which, stated simply, would allow research on surplus embryos for therapeutic purposes, genetic diagnosis pre-implantation, and the use of heterologous fertilization (i.e., donated sperm). All of these procedures are forbidden by law no. 40.

Italians answered the referendum questions by abstaining in huge numbers: 74.1 percent of the electorate did not vote, making it one of the lowest turnouts in Italian history. Since the required quorum of a 50 percent turnout was not reached, none of the proposed amendments to the law was adopted (cf. appendix, tables 9a-9d). The outcome of the referendum literally stunned many politicians, electoral analysts, and political scientists, who did not expect such a low rate of participation. One might be tempted not to see anything new in these results, given the growing

Notes for this chapter begin on page 180 . 
aversion among Italian voters for the referendum procedure. However, the entire episode of the law on artificial insemination is particularly significant for at least three reasons. First, it opened a public debate on issues that have become central to all Western democracies-those that are called "ethically sensitive" since they concern life and death, the family, and sexuality. At the same time, the bitter and harsh tones in which this discussion was conducted brought to light the weakness of Italian democracy in its search for a shared ethos on subjects of such a delicate nature. Finally, it raised again the topic of the relationship between secular culture and Catholic culture, and its complex connection with the development of bipolarism in the Italian political system.

In an attempt to offer an interpretation of all of these events, this chapter will analyze some aspects of them. First of all, it will go over the crucial steps that led to the approval of law no. 40. Next, it will examine the principal motives for the opposition to the law expressed by one part of the country, which led it to take the issue directly to the electorate, concentrating attention on the themes of the referendum campaign and on the positions taken by the political parties and groups in civil society. In the third part, there will be an analysis of the outcome of the referendum, suggesting possible interpretations. In conclusion, we shall try to indicate what effects the episode of law no. 40 has had on Italian politics and what the prospects are for the future.

\section{The Previous Regulation of Medically Assisted Reproduction and the Debate up until Law No. 40}

The progress of research on human reproduction and the spread, even in Italy, of MAR techniques, was not followed by a timely legislative action to regulate this field. Before law no. 40, Italy's system made up for a lack of legal regulation with a series of administrative measures that established limits and conditions for artificial insemination.

The administrative controls were certainly not particularly exhaustive, as they proved to be fragmentary and offered solutions only to the most urgent issues. The 1 March 1985 circular of the health minister, known as the Degan Circular, established the principal limitations on artificial insemination, allowing only married couples who were not separated to request medical treatment for reproductive pathologies and allowing only for "homologous" fertilization (that is, using gametes of the couple). These rules applied only to facilities belonging to the national health service or contracted to it and not to private clinics, where the use of heterologous insemination (using the genetic material of a donor) is widely practiced. 
At the same time, the governments that alternated over the years, often pressed by parliamentary motions, set up technical working groups to study and research the scientific, ethical, and legal aspects of reproductive biotechnology and genetic engineering. As long ago as 1990, the National Committee for Bioethics was created, and numerous other expert ministerial committees were subsequently formed with the specific mandate to prepare a document to serve as the foundation for a law on the subject. The fate of the materials they prepared was always the same. As one regular participant in the committees noted, the studies were assigned to "a drawer in the minister's desk, to which the key had been lost." "This public partial regulation was then complemented by the codes of conduct of the professionals involved. The total freedom left to private clinics did not mean, in fact, a total absence of rules in this sector. The private sector, over time, adopted rules of self-regulation via the norms contained in the medical ethics code approved by the National Federation of Colleges of Physicians, which closed the door to the spread of the more controversial practices. ${ }^{2}$

This rapid excursus shows that it certainly cannot be said that law no. 40 put an end to the "reproductive Wild West" that is so often spoken of. Rather, law no. 40 filled a "legislative gap" on the subject, introducing norms that, even though they have significant lacunae, provide a coherent regulatory framework. In this way, Italy came into line with the other countries of the European Union, the last of the 15 to do so, 20 years after Sweden passed the first law on the subject. The reasons for such a noticeable delay in legislating on the subject are still not clear: even with the inevitable difficulty of giving legal form to "ethically sensitive" issues, an inability and a lack of will to legislate have characterized what has been called the "Italian way" on the issue of artificial insemination. ${ }^{3}$

For a long time, the absence of rules was certainly not the result of a conscious choice between those who believe legislative intervention is necessary on this subject and those who think that legislation would infringe on an area that ought to be left to the free decisions of individuals. A public discussion of the matter never took place; the Degan Circular represented an option for partial regulation. In this way, the choice was avoided, and the debate (and conflict) that opened up with the advent of reproductive technology was defused. The conditions for parliamentary action appeared only in the course of the 13th Legislature, with the wave of anxiety created in public opinion by the first striking success of efforts at animal cloning, ${ }^{4}$ and also with pressure generated by growing European sensitivity on these issues. ${ }^{5}$

When the debate opened in this Parliament, controlled by a centerleft majority, on how and to what degree law-makers should regulate 
this subject, the difficulty of finding a middle ground became immediately obvious: right from the beginning the Catholics within both political coalitions and the Northern League voiced their total and intransigent opposition to access to reproductive technology for nonmarried couples and to donor insemination. In this situation, the leftwing parties in the governing coalition, in an attempt to overcome the split within the Ulivo, counted on support from the secular members of the center-right, particularly those from Forza Italia (FI). ${ }^{6}$

The next step was the drafting of a consolidated text, which (for the first time in Italian parliamentary history) passed the committee stage and reached the floor of Parliament; this was the so-called Bolognesi text, from the name of its rapporteur, a Left Democrat (DS) member of Parliament. But the expectation that it would elicit the degree of consensus necessary to lead to convergence on a common position, supported by a "secular" majority crossing the line between the two coalitions, was dashed: at the beginning of the debate on the floor, the deputies rejected the possibility of donor insemination. On the one hand, the vote held by secret ballot confirmed the "no" vote announced by the Partito Popolare Italiano (PPI), Alleanza Nazionale (AN), the Centro Cristiano-Democratico (CCD), the Lega Nord (LN), the Cristiano-Sociali (a Catholic group that joined the DS), and the Unione Democratici per l'Europa (UDEUR). On the other hand, it was evidence of the "betrayal" of FI. The text itself passed a third reading in the Chamber but not in the Senate.

At the beginning of the 14th Legislature, this time with a center-right majority in power, Parliament tried again. On 18 February 2002, the Chamber of Deputies approved the text that was to become law no. 40. It addressed all the key points of the debate: the aim of MAR, which techniques are permitted, how and when they may be used, and the so-called status of the embryo. First of all, artificial insemination was defined as a remedy allowed exclusively "in order to further the solution of reproductive problems derived from human sterility or infertility." This limitation in effect does not allow for the use of MAR to prevent the transmission of genetic illnesses through pre-implantation diagnosis. Secondly, the text speaks of a right to access only to the technique of "homologous" fertilization, and only for "couples consisting of adults of the opposite sex, married or cohabiting, of a potentially fertile age, both living." Therefore, the law prohibits donor insemination, as well as post mortem insemination. Thirdly, the law contains a series of provisions for the protection of the human embryo, starting from the declaration of principle that the law "ensures the rights of all persons concerned, including those who have been conceived." Any form of experimentation on embryos or eugenic selection is prohibited, 
as is the production of embryos solely for research; however, clinical and experimental research is allowed on the condition that its purpose is exclusively therapeutic and diagnostic and is aimed at protecting human health and assisting the development of the embryos. Lastly, crioconservation (that is, the freezing of embryos) and the destruction of embryos, except for those terminations of pregnancy permitted by law no. 194 (the abortion law), are prohibited. MAR techniques may not create more embryos than needed for a single implantation at one time, and in any case not more than three.

The final approval of this text was an extenuating process that took place in a climate of bitter polemics, but what is most striking is the lack of a constructive (and desirable) dialectic, which can be attributed to the rigidity of the positions of the participants. This can be illustrated by what happened during the Senate's consideration of the bill. At first, the representatives of the government majority demonstrated an openness and willingness to discuss the text; ${ }^{7}$ however, they then closed off the possibility of accepting any counterproposals to modify the more controversial aspects of the measure, even though the amendments had been frequently requested by a large number of highly qualified health workers and scholars who were heard during the discussion. In the face of this hardening of the majority's position, a cohesive minority group took shape, led by the DS together with a "secular" component of the center-right, who continued to the bitter end in their attempts to find common ground on modifications to the text. ${ }^{8}$ The hope of a compromise was frustrated on the one hand by the center-right's political decision to "fast-track" the law (i.e., require a vote on the bill without amendments) and on the other hand by the belief of the majority of the Margherita that any modification of the text would mean the continuation of an unregulated reproductive "Wild West." The Church hierarchy also entered the fray in support of the law, which it considered the only acceptable compromise. In their repeated interventions, Church officials appealed to the consciences of Catholic legislators to follow the values and fundamental principles of the teachings of the Church. Even Pope John Paul II publicly intervened, urging the Senate to approve the law quickly. ${ }^{9}$

Law no. 40 was passed by Parliament, giving rise to two "transversal" groups that crossed the boundary between the two coalitions. From a political point of view, this division re-created the old cleavage between Catholic and secular forces. In fact, almost all the representatives of the center-right voted "yes," as well as the Margherita, while the DS, Socialisti Democratici Italiani (SDI), Greens, Rifondazione Comunista (RC), and Partito dei Comunisti Italiani (PdCI) voted "no." 


\section{The Referendum Questions and the Campaign}

Putting aside the principled and ideological motives that inspired the major elements of law no. 40, the new rules on artificial insemination have sparked some doubts in light of a comparison with the ways that other countries have dealt with the matter. In contrast with other countries, the Italian law takes an extremely restrictive approach with peculiar results: as one observer has cogently remarked, "in various European countries this or that is prohibited but none of them prohibits all the things that Italy does." 10 The preference for a "prohibitionist" framework with regard to bioethics is often tied to cultural concepts related to fear of the impact of technology on human reproduction. It stems from the idea that the use of this technology has an explosive potential that could have very dangerous results, and thus the subject should be approached very cautiously. Because of their fear of possible unwelcome consequences, those who hold these beliefs favor a precautionary principle through the implementation of "reassuring" regulations that impose a series of rules and limits. ${ }^{11}$

To return to the case of Italy, a similar attitude helps to explain, at least in part, the choices with regard to both method and content in law no. 40. On the one hand, there was a predominant conviction that legislative intervention was absolutely necessary and could no longer be put off, or in any case it was the lesser evil compared to having absolutely no rules at all. This also explains the resistance of the Senate to requests to make even one correction to the text passed by the Chamber-they feared that reopening the debate could possibly have put at risk the majority backing for the law, a majority that was in any case fragile. On the other hand, the law uses the instrument of absolute and peremptory prohibitions. Many of these were acceptable and, in fact, broadly accepted. Others were excessive, and on these one might have expected a further consideration, given the diversity of opinions on the subject and the approach taken in the legislation of most neighboring countries.

By proceeding in this manner, the majority that passed law no. 40 ended up by imposing an exclusive and excluding logic. It is exclusive in that it is based on a particular point of view on a subject where the positions differ strongly, not only as a result of cultural and religious divisions, but also because of varying scientific opinions. From this point of view, law no. 40 cannot be defined as a "Catholic law," in that its content does not completely overlap with the Church's official doctrine on the subject, ${ }^{12}$ but at the same time it takes as its starting point the equality of the embryo with those already born. This reflects only one limited part of the positions of religion, science, and 
philosophy on the matter. It is also excluding because it has the effect of delegitimizing all of the positions that fall outside of the one that is legally imposed. In this way, however, it risks increasing and perpetuating the very conflicts whose prevention is one of the principal functions of law. ${ }^{13}$

The end of the parliamentary debate did not close the question of artificial insemination. On the contrary, the day after the approval of the law, five requests for a referendum on its repeal were put forward. One omnibus question, proposed by the Radicals and RC, asked for the repeal of the entire law, while the four other questions involved its partial repeal. Organized by representatives of the DS, ${ }^{14}$ these four questions aimed to correct certain significant points of the law, specifically those that had been most controversial in the scientific, political, and parliamentary debates. All of the questions passed the examination by the Constitutional Court, with the exception of the total repeal, which was judged as inadmissible since it deprived the system of "constitutionally necessary" regulations. ${ }^{15}$ On all of the other questions, however, the referendum campaign began. It promised to be bitterly fought, with possibly very divisive effects on the country, and thus generated uncertainty and concern. It is not accidental that following the decision that the four questions were admissible, the political debate at first centered on whether Parliament should amend the articles whose repeal had been requested before the referendum took place. In the Senate, various bills were submitted by representatives of the majority and of the center-left in an ultimate attempt at mediation, but these limited initiatives, not adequately underpinned by a shared political will, were destined to failure.

Citizens were thus called to state their opinions on extremely specific questions, such as the admissibility of genetic diagnosis pre-implantation, the limits of stem-cell research, and, indirectly, the status of the embryo. The first question in the referendum aimed to eliminate the prohibition of the experimental use of surplus embryos for therapeutic purposes. The intention was to allow scientific research on illnesses that at the moment are incurable. The second question dealt with the limit on the number of embryos that could be implanted in a woman. In order to avoid the production of surplus embryos, the law requires that no more than three embryos be created in vitro and that they be implanted all at one time, whatever the possibility of success. The referendum's proponents called for the elimination of these limitations, arguing that they could damage the woman's health, given that she would risk being exposed to repeated ovarian stimulation because under these regulations there would be a lower probability that each implant would succeed. If this question had been approved, it would 
also have permitted three other procedures prohibited by the law: pre-implantation diagnosis, embryonic selection, and the freezing of embryos. The aim was therefore to extend to couples carrying genetic disorders (as well as those that are sterile) the right to resort to artificial insemination. The third question deleted from the law the reference to the "rights of the conceived." This proposal technically would not have any effect, but it would have great symbolic value because of its implications for the question of establishing the beginning of the life of a "human being." Finally, the fourth question proposed to eliminate the prohibition on techniques of donor insemination, as well as the associated penalties.

The positions of the political forces on the referendum questions were not far from the positions they had taken in Parliament, but this time the parties' decisions were overtaken by another factor that was going to be decisive: the Church mobilized in favor of abstention in the referendum. This course was suggested by Camillo Ruini, the president of the Conference of Italian Bishops (CEI), and adopted by the leaders and representatives of almost all the Catholic movements and associations, who founded the "Science and Life for the Support of Law No. $40 " 16$ committee. The signatories of its manifesto expressed a "double no": first, on the content of the referendum questions, which would have subverted a law that they considered "not perfect" but "that ensures that every child has the guarantee of a life and the protection of a real family"; second, on the improper use of the institution of the referendum on the subject of artificial insemination.

Faced with this abstentionist position, only parties of the left voiced their "yes" to the four questions. On the other side, the center-right coalition positioned itself alongside the abstentionist movement, with the exception of a fringe group inside the FI party and the leader of AN, Gianfranco Fini. The Margherita officially chose the line of "freedom of conscience," but the principal representatives of the Catholic section of the party and its leader, Francesco Rutelli, declared their intention not to go to the polls.

The call for abstention as a means of defending the law caught the supporters of the referendum off guard and shifted the theme of the debate to the slogan "on life one does not vote." The formulation of the referendum questions raised matters that on the one hand were very specific, requiring precise scientific knowledge, and on the other were complex issues with major moral implications. As such, it was difficult to respond with a simple "yes" or "no," as is standard for a repeal referendum. Voters were asked to consider the following: Is it reasonable for an embryo to enjoy greater protection than a fetus in a system where one is allowed to terminate a pregnancy, but no medical 
interference with embryos is permitted? What is the appropriate balance between two rights that both deserve protection-the physical and mental health of women on one side, and the right to life of those who have been conceived on the other? Is it suitable in every case to forbid the use of donor insemination on the basis of an exclusively biological model of parenthood?

In fact, the promoters of the referendum, belonging or close to the DS, were at first wary of taking the referendum route before deciding to bet on the possibility of involving public opinion in a "pragmatic" discussion. Their objective was to achieve what they had failed to obtain in Parliament-not to throw out the law, as the Radicals proposed in their question, but rather to correct the points they considered critical. ${ }^{17}$ Yet in the end, the referendum campaign marginalized the debate on the substance of the individual problems. It was dominated by other key protagonists, whose impact was all the greater because the campaign was concentrated in the month and a half preceding the vote. The regional elections were now over, and the media focused their spotlight on the referendum.

The first problem is represented by the great question that stood out in the background of law no. 40-the topic of the embryo and its status, found in the third referendum question. Without a doubt this was the most complex issue with the strongest social and emotional impact, but it was also the most "slippery," since it allowed the debate to slide into the terrain of ideology. On the substance of this question, all positions-philosophical, cultural, and religious - were legitimately expressed, a demonstration, if any were needed, of how broad the range of opinions is, even in Italy. Meanwhile, the debate leading up to the referendum became a confrontation between two simplified, extreme theories: the affirmation of the personhood of the embryo, which required the defense of the law with all its prohibitions and limitations, and the argument that it is acceptable to perform experiments on and manipulate embryos.

There was no lack of moderate positions, such as that of Giuliano Amato, who proposed to find a common ground in the acknowledgment of the "human dignity" of the embryo. ${ }^{18}$ But these positions were overshadowed by the predominant trend toward the radicalization of the conflict. This was symbolized by the leading speakers at the closing rallies of the referendum campaign: ${ }^{19}$ representing one side was Marco Pannella, the leader of the Radicals, who had organized the rejected referendum proposal to repeal law no. 40 altogether, and representing the other side was Giuliano Ferrara, the editor of Il Foglio, who was the best-known supporter of "Operation Theocon," which contributed to George W. Bush's victory in the last American election. 
One could say that in fact only one of the two conceptions of the referendum initiative prevailed in the end, that of the Radicals, which had been initially sidelined by the Constitutional Court. It crowded out the "reformist" position based on the four partial questions, which failed in its objective of channeling the discussion along the lines of amending the law point by point. The centrality that the embryo argument took on created an imbalance between the positions in the debate. Faced with an argument of principle such as the value of life, used by the abstentionists, the promoters of the referendum were not able to shift the focus of the discussion to the concrete topics that the people would be voting on.

During the discussions that followed, it proved impossible to limit the debate to the letter of the law because the questions revived bioethical and religious dilemmas, one of which was the role of science and its social effects. Many times, in the columns of the Corriere della Sera, Ernesto Galli Della Loggia urged his readers not to evade the fundamental question of the ethical limits to the application of the techniques and discoveries of scientific research (in the field of reproduction, in the first place) ${ }^{20}$ He asked them to distinguish between that which can be objectively established by science, which only experts can determine, and that which is morally and ethically acceptable, which all citizens of Italy had the responsibility of deciding. This led to a discussion of the relationship between science and ethics and of the equally important connection between science and religion. The parties and their leaders all seemed to avoid these themes and failed to offer any guidance on this issue by suggesting an ethical vision of science or a set of standards of behavior that could serve a society undergoing enormous change. A large part of the Italian scientific community, however, mobilized publicly. Although they were divided, most scientists supported the pro-referendum camp in the name of the freedom of research and out of opposition to old and new anti-scientific prohibitions. ${ }^{21}$

During the course of the referendum campaign, the polemic over the Church hierarchy's appeal for abstention was like a constant noise in the background. The bishops, considering it the most effective way to defend the law that they had already "supported" in Parliament, introduced the notion of abstention even before the discussion of the various options began and the authors of the law had weighed in. Many criticisms were directed at the propaganda campaign for abstention: its legal legitimacy was not in question, although the issue has been debated at length by influential scholars. But the supporters of the referendum viewed the abstention campaign as a crafty expedient, a politically unethical technical contrivance that would make opening 
up a debate on the merits of the questions even more difficult. They argued that it was a symptom of the weakness of the ethical arguments advanced to support abstention. The fact that the invitation to abstain came from the Church gave some the opportunity to deplore the Church's increasing involvement in temporal matters and to defend the autonomy of the state and civil society in the face of this trend. Others, in more measured tones, pointed out that it raised the issue of what constitutes a secular democracy and what role the dialogue between political actors and religious authorities should have. ${ }^{22}$

The referendum, then, raised many themes that engaged the public in a debate that was certainly not useless, once we discount the multiplier effect of the polemical intensity that is part of every electoral campaign. But, given the multiplicity and heterogeneity of the questions, the reasons behind the "yes" and "no" positions on the partial repeal of the law got lost in the excess of arguments.

\section{The Results of the Referendum}

As we have already mentioned, on 12 and 13 June, the voter turnout was 25.9 percent, the lowest in Italian repeal referendum history alongside that in the 2003 referendum on Article 18 of the Statute of Workers' Rights (25.7 percent). It was clear enough to all that it would be impossible to achieve the quorum of 50 percent, but no one had expected such a high level of abstention. To the promoters of the referendum, a turnout that was less than the quorum but around 40 percent would have been useful as a demonstration of strength, since at that figure they would have been able to delegitimate parts of the law, if not to repeal them. This did not occur. Therefore, the "yes" side's victory was useless, even though it won about 88 percent of the votes cast on the first three questions and 78.2 percent on the question on donor insemination.

Since there were numerous themes raised in the campaign, once the polls closed commentators offered diverse interpretations of the mood of Italian society as revealed by the vote, depending on the vantage point from which it was viewed. Some spoke of a critical or negative attitude toward scientific research, or of a revolt against the party elites. Some advanced the hypothesis of a new alliance between secular conservative tendencies and integralist leanings within the Catholic camp. Rather than starting from these reconstructions, however, it may be more prudent to limit our analysis to the facts, using the available data and concentrating our attention only on certain aspects.

A reading of the referendum results (see the appendix, tables $9 \mathrm{a}-9 \mathrm{~d}$, for the summary data) shows, first of all, the geographical differentiation 
of the vote. We can see, in particular, a clear disjunction between the Northern and Central regions, on the one hand, and the South, on the other: the voters in the former were roughly twice as likely to come out to the polls as the latter. In any case, in no region or province was the quorum met, though the highest turnout was registered in the regions with the strongest bond linking the electorate to the left-wing parties. At this point it is more difficult to analyze the vote according to other categories. A study conducted by the SWG polling firm using data collected before the referendum suggested that gender was not a significant variable: women did not show up as predominant among those who voted in the referendum. The age of the voter seemed to have a greater influence, with those over 55 more likely to abstain. The level of education had even more impact: secondary and postsecondary graduates accounted for almost 50 percent of the voters, but only 38 percent of the abstainers. ${ }^{23}$

More than anything, though, the analysts emphasized the large number of non-voters, which was higher than all expectations and open to various interpretations. If we consider Italian society as a whole, the 75 percent abstention rate is a sign of widespread disenchantment, disinterest, or even what the sociologist Giuseppe De Rita has called referendum-induced "political/media stress." 24 It is clear that there are varying types of abstention: behind the "silence" of two-thirds of Italians there were distinct states of mind, differing motivations, and various types of indifference. There is always a certain amount of non-voting due to disinterest or inertia, but its extent this time was a reflection of the disfavor into which the institution of the referendum has fallen. Those who abstained to make a point about the political system could easily be confused with disinterested voters. But there were also those who did not vote for reasons that stemmed specifically from the subject matter of the referendum.

On this last point we can refer to the research done by the Cattaneo Institute, which elaborated a model to predict the results of the referendum vote that proved to be extremely accurate. The experts at the Institute, using their own data, estimated that the rate of turnout would be 27.4 percent, very close to the actual figure. To reach this result, they hypothesized that all of the voters would follow the suggestions of the leaders of their reference groups, political or ecclesiastical, with some variation according to the clarity with which the latter expressed their positions. Thus, the more unequivocal the message, the more the voters would be united in following it. Vice versa, the voters who received contradictory suggestions or whose leaders took no official position (for example, voters whose parties chose the "freedom of conscience" stance) would be evenly divided between abstention and voting. ${ }^{25}$ This 
predictive model, whose validity is confirmed by its great accuracy in estimating geographical voting differences, offers a starting point for some further reflections on its substantive findings.

The choices that Italians made in the referendum were greatly affected both by the actions of the parties, which often crossed the boundary between the two coalitions, and by those of the Church. According to the Cattaneo Institute's comparison of the expectations of their model with the actual results, "neither of the two coalitions of elites (pro- and anti-referendum) managed to encroach significantly on the constituency of the other," 26 considering that in any case it was more difficult to mobilize Italians to go to the polls than to convince them to abstain from voting. This rules out the more extreme interpretations of the vote: the failure of the referendum was not a symptom of the eclipse of politics itself, since the activity of the political forces had a decisive influence on the orientation of the citizens. If anything, it points to an error in political judgment committed by the leaders of the groups that promoted the referendum, who probably underestimated the moods and tendencies present in society and thus supported an initiative that was destined to fail. On the other hand, the outcome of the referendum cannot be read as the victory of an ethical and political position of exclusively Catholic origin, a clerical revanche on secular Italy, even less as the reflection of a country divided by a deep split between Catholic and secular camps. Indeed, all the initial evaluations of the analysts highlight the fact that each of the two halves of the electorate-those that abstained and those that voted-cut across the two camps, containing both Catholic and secular voters.

The fact that the expressed positions of the voters were greatly influenced by the positions of the organizations that they used as reference points confirms the difficulty and the sense of inadequacy that was generated by questions that were too complicated and abstract, and over which it seemed that opposing extremes were fighting on very uncertain terrain. For Italians disoriented by the referendum, whose ethical and scientific aspects they were unable to come to terms with, the words of the leaders to whom they felt closest gave them a point of reference for their voting decision. ${ }^{27}$ From this perspective, the results of the vote were a defeat for the referendum strategy as a means of amending a law that many considered unsatisfactory. It thus demonstrated-to use the words of Ilvo Diamanti-that for subjects of such a delicate and complex nature, "we cannot entrust direct democracy with the task of substituting for representative democracy." 28

These observations force us to ask whether we can consider the referendum vote as a judgment on the part of Italians vis-à-vis the content of law no. 40. Technically, the victory of the abstentionist camp has no 
effect on the law that was submitted to referendum; it is not equivalent to a confirmation of the law (which would have happened with a winning "no" vote) and in any case cannot prevent Parliament from subsequently modifying it in any way whatever. In its ambiguity, abstention obviously does not give any certainty as to the opinion of the country.

Nevertheless, some opinion polls offer starting points for further thoughts. In the months preceding the referendum vote, a relative majority of Italians declared, according to some surveys, that they were in favor of some modifications to the law. ${ }^{29}$ When asked to answer detailed questions, such as those that would be asked in the future referendum, they demonstrated a similar propensity. A report titled "Biotechnology and Public Opinion in Italy," prepared by Observa in collaboration with the National Committee on Biotechnology in the autumn of 2004, stated that 68 percent of Italians believed it was "morally acceptable" to use human embryonic stem cells for research, and 76 percent considered this research "useful." ${ }^{30}$ Finally, research carried out by ISPO confirmed this position: after the referendum, 46 percent of those surveyed said they were in favor of limited modifications to law no. 40, 16 percent were in favor of radical modifications, and 26 percent believed it should not be changed at all. This means, in the first place, that in Italy there is a large majority (62 percent) that is in favor of revisiting law no. 40 with a view to improving it, a balance of opinion that probably existed even before the referendum. In the second place, the opinions of Italians are varied but not polarized. Therefore, an intermediate position ("partial modifications") prevails over more rigid ones ("radical modifications" or "no change"). ${ }^{31}$

In light of this data, Italy does not seem to be a nation polarized on the issue of artificial insemination. The clashes of radically opposed positions in Parliament or in the referendum debates do not seem to reflect public opinion. Instead, the picture that emerges is that of a nation searching for a balanced solution. In this sense, it can be said that abstention from voting in the referendum-occasioned by a mixture of detachment and discomfort-rather than indicating a defense of the law, was an attempt to return the discussion to Parliament, so that it might reach an agreement on a set of regulations that could attract a reasonably broad consensus.

\section{The Political Implications}

It is true that the referendum vote cannot be read as a partisan political vote, in the narrow sense. It is difficult, for example, to place it alongside that of the regional elections that were held only slightly 
earlier, which altered the political geography of the country, with the center-left sweeping 12 out of 14 regions. It is just as true, however, that the entire MAR episode sheds light on two different trends within the opposing political coalitions.

Above all, this issue can be used as a litmus test to discern whether the center-right coalition is evolving from a meeting ground for conservative political forces, with a strong internal liberal component, into a clerical-moderate or Catholic-conservative grouping. The moment that symbolizes the start of this sort of "genetic mutation" dates from the previous legislature and coincides with the defeat of the Bolognesi text, which was the result of the position adopted by FI against the opinion of the secular members in its ranks. From that moment, the center-right has tried to present a united front on reproductive issues and, more generally, in the area of "ethically sensitive" questions. This is what happened with law no. 40 and the referendum on it, which were a partial success for this operation. That the politics of the center-right has passed a turning point is confirmed in particular by the role of the Union of Christian Democrats and Center Democrats (UDC), which not coincidentally began to assert itself more within the coalition after the referendum vote. The day after the referendum, the speaker of the Chamber, Pierferdinando Casini, said that if his coalition wanted to win elections again, "it must take on board the lessons of the referendum and respond to the demand for values that today only the Church seems able to offer." 32 The temptation for the centerright to refashion its identity in this direction stems, then, from an obvious calculation of electoral advantage: it reckons that it could aim to get more electoral support among that swath of uncertain voters who do not identify a priori with one of the contending coalitions, but who may respond to an appeal to values. In the imminent electoral contest, the center-right could use the theme of values strategically with respect to other topics, starting with economic issues, on which they will have to defend their record as a government to the country. This might allow them to shift the center of the debate from the political and programmatic plane to that of ideology and values.

For the center-left, on the other hand, the issues are different, although connected to those of the center-right. The different positions adopted by the two principal partners in the coalition, the Margherita and the DS, both in Parliament and in the referendum campaign, created the image of a divided rather than a pluralistic coalition. This in fact set back the original project of the Ulivo to ally the Catholic reformist movement with its secular and socialist counterpart. Beyond the contingent circumstances of the referendum, this experience symbolized the still imperfect fusion between the two political souls of the 
coalition. This point is reinforced by each party's interpretation of the outcome of the referendum and of the position of the other. Within the Margherita, which did not give the electorate an indication of how it should vote, many theorized that there should be internal pluralism on the theme of bioethics, and there were warnings that uniformity on these matters brings with it a risk of falling back on ideological positions. This attitude was based on, first, an "internal" consideration, that is, that to adopt any position would in itself have created a division within the party, and, second, an "external" consideration, that is, the belief that the "freedom of conscience" approach would allow the party to speak to a broader electorate.

The DS, on the other hand, chose to offer themselves as a small experimental laboratory to test the interaction of the same dynamics represented within the coalition. In this sense, the successful attempt to create a synthesis between the diverse currents of thought in the party, despite the referendum defeat, counts as a sign of maturity. As a result, the DS suggested going beyond the "freedom of conscience" approach and, with a view to a future government, constructing a shared position with their allies, which could then take a prominent place in the development of the center-left's program. This is a crucial point at issue, both political and cultural, that is anything but irrelevant from the perspective of the construction of a Democratic Party that would see the two political partners united in a single entity. Despite the "moderate" position that Rutelli assumed in the debate, it should be noted that one of the three matters that he clearly put to the DS as conditions for concretizing this idea was "the need to cultivate a deeper democratic pluralism in the new organizational forms of politics ... which cannot fall under the sway of a hegemonic pattern of thought or a single political orientation (whether, for example, secular or confessional)." 33 In this context, the recent decision of the committee drafting the program of the Unione to commit the coalition to resolving two ethically sensitive issues, civil unions for same-sex couples and posthumous organ donation, ${ }^{34}$ may allow us to measure its ability to find a common solution to the problem.

\section{Conclusions}

A few weeks after the polls closed, a newspaper ran an article with the eye-catching title, "No More Artificial Insemination," to point out the danger that the debate over law no. 40 would peter out. In effect, there are several factors which suggest that the issue will be taken off the political agenda, at least in the short term. As far as a parliamentary 
initiative is concerned, it is clear that the center-right is not prepared to modify the law, which they believe could be adjusted and corrected only at the end of the mandated three-year trial period. On the other hand, for the center-left to take up the issue again, it not only has to win the next election but also must manage to formulate a common position. In any case, neither of the platforms of the two coalitions mentions law no. 40. It is instead more likely that it could return to the political agenda after the Constitutional Court issues its expected ruling on the legitimacy of the article that prohibits pre-implantation genetic diagnosis.

Nevertheless, dismissing the referendum would clearly be an error, especially if one aims to understand Italian society or give an accurate account of it. Among the serious risks it faces is that ethical issues may be reduced to a new terrain for political competition-a risk that is present in other major democracies, as George W. Bush's United States, on the one hand, and in part Rodríguez Zapatero's Spain, on the other, demonstrate. This may lead to an "ethical bipolarism" in which the opposing coalitions radicalize the conflict on ethically sensitive subjects. In this way, laws on extremely delicate topics that involve the essential values of the community would be subject to amendment with each shift in the parliamentary majority. ${ }^{35}$ The entire MAR episode offers several instances in which politicians were tempted to act in this way. And yet the outcome of the referendum, beyond the surprise at the rate of voter participation, should lead to reflection on the need to safeguard a pluralism of ethical points of view through the search-which must be above all political-for a mediation that respects each one of them, both in the debate on these issues and in the laws that regulate them. The referendum was a signal that civil society cannot be understood through the prism of the historical division between Catholic and secular forces and that issues related to the use of biotechnology cannot be approached by employing the same concepts and the same cultural framework that furnished the weapons for the battle for civil rights in the 1970s.

The issue is delicate, and at the same time it seems more urgent if we look beyond the narrow confines of Italy. In 1978, when the Italian abortion referendum was being conducted, the first test-tube baby, Louise Brown, was born. Almost 25 years later, while in Italy the first law on the subject was being passed, news was coming in from other parts of our globalized planet about the latest research delving into "the book of life." Universities, governments, and businesses from such countries as the US and Great Britain, and even China and South Korea, are investing resources in stem-cell research and therapeutic cloning. For some time already it has seemed likely that biomedical 
research will be one of the fields where international competition will be intense. Preparing to confront this phenomenon and understanding how to control it has no doubt been valuable, but what is needed is a commitment to continue down this road. The referendum questions on law no. 40, which served to raise public awareness on issues that are relevant for our times, highlight many challenges on which Italy, too, will soon have to reflect once again.

- Translated by Cora Stern

\section{Notes}

1. C. Flamigni, La procreazione assistita (Bologna: Il Mulino, 2002), 118.

2. Many countries, including the United States, still rely on professional standards of ethics as a way of regulating reproductive technology. See the information collected by the International Federation of Fertility Societies (IFFS) in its report "IFFS Surveillance 04" (http://www.iffs-reproduction.org).

3. This expression is used by P. Zatti, "Verso un diritto per la bioetica: Risorse e limiti del discorso giuridico,” Rivista di diritto civile, no. 1 (1995): 45.

4. As C. Valentini notes in her book, La fecondazione proibita (Milan: Feltrinelli, 2004), 117-118.

5. On 4 April 1997, the convention of the Council of Europe on human rights and biomedicine was approved in Oviedo. While it does not directly address the issue of artificial insemination, it does stress the need for clear rules on the subject.

6. For a fuller discussion, please consult C. Martini, "Il dibattito parlamentare sulla Pma nella XIII e XIV legislatura," in La ricerca e la coscienza: La procreazione assistita fra legge e referendum, ed. G. Tonini (Rome: Edizioni Riformiste, 2005).

7. At the beginning of the Senate debate, the mover of the bill for the government majority, Senator Flavio Tredese (FI), said: "The law as it is now cannot be applied. It contains some absurdities. We have to correct it, otherwise we will find ourselves with useless rules" (Corriere della Sera, 18 September 2002).

8. The five critical points on which the opposition asked the government to negotiate and on which it focused its amendments are listed in the "minority report" presented by DS Senator Giorgio Tonini.

9. O. La Rocca, La Repubblica, 23 May 2003.

10. Tonini, La ricerca e la coscienza, 97. For a brief but complete overview of European legislation, cf. V. Franco, Bioetica e procreazione assistita (Rome: Donzelli, 2005), 118-122.

11. This is the position that Mary Warnock calls the "slippery slope" in Fare bambini: Esiste un diritto di avere figli? (Turin: Einaudi, 2004), 46.

12. For Catholics, the guiding principles are formulated in Donum Vitae, the instruction issued on 22 February 1987 by the Congregation for the Doctrine 
of the Faith: protection of life from the moment of conception, condemnation of any form of procreation other than natural sexual intercourse by married couples, and prohibition of any medical procedure involving a human embryo that is not strictly necessary for the health of the embryo itself.

13. See the reflections of $\mathrm{S}$. Rodotà, based in part on the experience in other countries, in Tecnologie e diritti (Bologna: Il Mulino, 1995), $147 \mathrm{ff}$.

14. The Radicals subsequently also supported these questions.

15. The Constitutional Court ruled on the questions in its decisions of 28 January 2005, nos. 45-49, available at www.cortecostituzionale.it.

16. The manifesto of the committee and the list of signatories are published in Avvenire, 20 February 2005.

17. See the interview with the secretary of the DS, Piero Fassino, in La Stampa, 9 May 2005.

18. Corriere della Sera, 11 April 2005.

19. C. De Gregorio, La Repubblica, 21 May 2005.

20. Corriere della Sera, 6 October 2004.

21. Ar.M., Il Sole-24 Ore, 18 May 2005.

22. See the reflections of G. E. Rusconi on this point in "La legge sulla fecondazione: Un'occasione mancata di democrazia laica," Il Mulino, no. 2 (2005): 221-228.

23. The surveys were carried out in the period November 2004-June 2005. The results are contained in SWG's report, "Il referendum sulla fecondazione assistita" (July 2005).

24. Corriere della Sera, 13 June 2005.

25. The model used by the Cattaneo Institute was based on the results of the last general election, combined with two other variables measuring the effects of the positions of the various parties and that of the Church. The prediction was based only on the pool of potential voters obtained by calculating the typical turnout for a referendum. The number of Catholics among each party's voters was used to estimate the influence of the Church. The results of the study are discussed by S. Vassallo in "La 'missione impossibile' di un referendum," Il Mulino, no. 5 (2005): 931-935.

26. Ibid., 934.

27. What Salvatore Vassallo calls the "most reliable cognitive short-cut" (cf. ibid., 933).

28. Il Sole-24 Ore, 16 June 2005.

29. According to the surveys conducted by SWG, for instance, the percentage who said during the campaign that they were in favor of changes to the law oscillated between 48 percent and 53 percent.

30. M. Bartolini and F. Cerati, Il Sole-24 Ore, 15 March 2005.

31. ISPO, "Le questioni eticamente sensibili: Le opinioni degli italiani" (research report, October 2005).

32. Interview with M. Calabresi, La Repubblica, 16 June 2005.

33. Europa, 28 October 2005.

34. M. Guerzoni, Corriere della Sera, 6 December 2005.

35. See on this point the reflections of A. Barbera and S. Ceccanti, "Un principio di maggioranza mitigato contro il rischio di un bipolarismo etico," Il Riformista, 20 August 2005. 